\title{
Развитие медиакомпетентности учащихся посредством видеосъёмки с элементами театрализации
}

В статье обоснована актуальность и эффективность использования видеосъёмки с элементами театрализачии как средства формирования лингводидактической коммуникативной компетентности и медиакомпетентности. Подчёркивается значимость интеграчии медиаобразования в преподавание иностранного языка вусловиях влияния технологических достижений цивилизации и средств современной коммуникации (компьютерных технологий, видео и т.д.). Раскрывается сущность философской теории, на базе которой возможен анализ развития медиакомпетентности и иноязычной коммуникативной компетентности учащихся.

Ключевые слова: медиакомпетентность, медиаобразование, медиакультура.

Влияние технологических достижений цивилизации и средств современной коммуникации (компьютерных технологий, видео, прессы, кино, радио, телевидения) на развитие мировой языковой индустрии потребовали расширения функций иностранного языка как учебного предмета и, соответственно, уточнения целей его изучения в современном обществе. В связи с этим особую значимость приобретает формирование у учащихся медиакомпетентности. То есть, возникает объективная необходимость в разработке моделей и технологий включения медиаобразования в учебный процесс современной школы.

Медиаобразование рассматривается как процесс развития личности с помощью и на материале средств массовой коммуникации (медиа) с целью развития культуры общения с медиа, творческих, коммуникативных способностей, критического мышления, умений полноценного восприятия, интерпретации, анализа и оценки медиатекстов, обучения различным формам самовыражения при помощи медиатехники [7].

Инфраструктура современного общества с его доступом к многообразию информации и ценностей дает прекрасную возможность для развития творческой, медиакомпетентной личности. Это хорошо понимает и правительство России, которое утвердило Концепцию долгосрочного социально-экономического развития Российской Федерации на период до 2020 года. Среди приоритетных направлений развития информационно-коммуникационных технологий в Концепции называется медиаобразование. Это свидетельствует, что необходимость и актуальность медиаобразования теперь признается на самом высоком государственном уровне, и становится задачей не только энтузиастов, но и государственного масштаба

Интеграция медиаобразования в образовательную сферу поощряется и на международном уровне, По инициативе ЮНЕСКО при поддержке Совета Европы 21-22 июня 2007 года в Париже прошла международная конференция, 
результатом которой стала разработка 12-ти практических рекомендаций в области медиаобразования [4]. Эти рекомендации применимы для всех заинтересованных лиц на всех уровнях внедрения, а также координации на местных национальных, региональных и международных уровнях. Ссылаясь на свой собственный опыт, как учителя английского языка, можно утверждать гармоничность союза медиаобразования и иностранного языка, так как в их основе лежит объединяющая идея - идея коммуникации. Интеграция медиаобразования в преподавание иностранного языка способствует развитию иноязычной коммуникативной компетентности и медиакомпетентности учащихся.

В такой ситуации аудиовизуальное искусство, а в частности - видео с элементами театрализации, как чрезвычайно сильное средство воздействия на людей всех возрастов приобретает особую значимость. Оно создаёт атмосферу доверительности, непосредственности общения, что при изучении иностранного языка позволяет погрузить учащихся в языковую среду, снять языковой барьер, развить медиакомпетентность, избежать формального подхода, создать комфортную рабочую обстановку на уроке, повысить мотивацию к предмету.

Одна из теорий, на базе которой возможен анализ современных тенденций развития медиапедагогики, направленных на формирование средств, условий и механизмов самодетерминации личности, развития творческих способностей, эффективного обучения иностранному языку - философская теория «диалога культур» В.С. Библера и М.М. Бахтина. Диалог есть взаимодействие, а формы взаимодействия представляют собой различные виды диалогических отношений, таких как, например, диалог наций, диалог учителя с учениками, диалог между человеком и техникой, диалог автора произведения и зрителя или читателя. Только в результате взаимодействия, диалога культур, возможна самореализация каждой из культур, самореализация личности.

Медиакомпетентность способствует «диалогу культур», соответственно и самореализации личности. А в интеграции с изучением английского языка - вдвойне. В основе обучения медиакомпетентности и иностранному языку лежат коммуникативный и интерактивный подходы. Видеосъемка сприменением театрализации, по нашему мнению, в наибольшей степени помогает реализовать эти подходы на практике. Диалогические отношения можно проследить и во взаимодействии учеников с камерой, так как она позволяет воплотить виртуальные желаемые образы в реальные, наполнить их определенным смыслом. Мы согласны с Н.Ф. Хилько, который отмечает, что «культура техники включена в личностные и технологические преобразования, где основной акцент делается на продуктивное развитие личности при условии ценностной ориентации деятельности» [6, с. 26].

Внедрение театрализованных элементов методически оправдано, ведь профессии учителя и актера имеют много общего. Между учителем и учениками, как и между актерами и зрителями должен поддерживаться постоянный диалог. Процесс обучения - не простая трансляция знаний, это двусторонний процесс, где «как режиссёр в процессе репетиций, так и учитель на уроке должны обладать 
способностью яркого эмоционально-волевого воздействия на актёров или учеников, учитель необходимо построить логику учебного процесса так, чтобы он был воспринят и понят учениками» [1, с. 5]. Театр позволяет раздвинуть границы реального существования и прожить в «предлагаемых обстоятельствах». В качестве «предлагаемых обстоятельств» могут выступать и пространство темы занятия, и пространство медиатекста. Театр позволяет реализовать принципы личностноориентированного, диалогового взаимодействия. Использование театрализованных элементов позволяет увидеть и развить способности учеников, дает возможность учителю и ученикам проявить себя как творческую личность, лучше понять другую культуру, погружает в языковую среду.

Английский язык здесь служит мостом, который связывает культуры. Чтобы вступить в достойный диалог с представителями других культур необходимо знать и понимать эти культуры. Мы согласны с М.М. Бахтиным, который считал, что понимание должно быть творческим, культуры должны взаимообогащаться. «Чужая культура только в глазах другой культуры раскрывает себя полнее и глубже...между ними начинается как бы диалог, который преодолевает замкнутость и односторонность этих культур. При такой диалогической встрече двух культур они не сливаются и не смешиваются...но они взаимно обогащаются» [2, с. 334]. И язык является отражением культуры, мощным источником её структуности «...В реально-историческом функционировании язык и культура неотделимы: невозможно существование языка (в полнозначном понимании этого слова), который не был бы погружен в контекст культуры, и культуры, которая не имела бы в центре себя структуры типа естественного языка» [3, с. 486].

Знаковый характер присущ не только языку, но и аудиовизуальному творчеству. С помощью символов человек создает свой собственный язык, который отличается многоплановостью, многозначностью. Восприятие аудиовизуального творчества всегда диалогично. Ю.Н. Усов отмечал, что осмысление многоплановости прочитанного или увиденного происходит в результате выявления значений (слов, кадров), соединение их в новом понятии (словосочетания, кинофразы) и определения к ним своего отношения [5].

Диалог культур в обучении английскому языку может эффективно осуществляться с использованием экранизаций и спектаклей, с созданием собственных видеопродуктов с элементами театрализации на английском языке, с их обсуждением как в своем коллективе, так и с носителями языка. Ведь художественные произведения, театр, фильмы, музыка - форма существования ценностей, мощные средства воздействия на личность. Они позволяют создать языковую среду общения, в наибольшей степени приближенную к реальной ситуации общения в жизни. К тому же они обладают культурным контекстом прошлого, настоящего и будущего, что также важно для создания диалогических отношений.

Таким образом, видеосъемка с элементами театрализации, соединяющая в себе театральное и медийное творчество, в наибольшей степени помогает реализовать коммуникативный и интерактивный подходы на практике. Театр позволяет 
реализовать принципы личностно-ориентированного, диалогового взаимодействия, существовать в «предлагаемых обстоятельствах», которыми могут выступать и пространство темы занятия и пространство медиатекста.

Диалогические отношения можно проследить и во взаимодействии учеников с видеокамерой, так как она позволяет воплотить образы в аудиовизуальные, наполнить их определенным смыслом.

При условии ценностной гуманистической ориентации деятельности, медиакультура способствует продуктивному развитию личности. Театр, фильмы, музыка, художественные произведения как формы существования культурных ценностей - мощные средства воздействия на личность, к тому же они погружают в языковую среду.

\section{Литература}

1. Басина Н.Э. Театральная педагогика как средство создания развивающей образовательной среды. Образовательная программа повышения квалификации педагогов и руководителей образования. - Екатеринбург: Изд-во АМБ, 2005. - 160 c.

2. Бахтин М.М. Эстетика словесного творчества. - М.: Искусство, 1979. - 424 с.

3. Лотман Ю.М. Семиосфера. - С.-Петербург: «Искусство-СПБ», 2000. - 704 с.

4. Парижская программа или 12 рекомендаций по медиаобразованию. - 2007 // http://www.ifap.ru/pr/2007/070625ba.pdf

5. Усов Ю.Н. Основы экранной культуры. - М.: Новая школа, 1993. - 90 с.

6. Хилько Н.Ф. Педагогика аудиовизуального творчества в социально- культурной сфере. - Омск: Изд-во ОмГу, 2008. - 210 с.

7. Fedorov A. On Media Education. - Moscow: IPOS UNESCO "Information for All", 2008. - 157 p. 